\title{
THE EFFECT AND MECHANISM OF CHLORIDE ION ATTACK ON PORTLAND CEMENT CONCRETE AND THE STRUCTURAL STEEL REINFORCEMENT
}

\author{
U.A. BIRNIN-YAURI ${ }^{1,+}$ and S. GARBA ${ }^{2}$ \\ 1. Department of Pure and Applied Chemistry, Usmanu Danfodiyo University, Sokoto, Nigeria. \\ 2. Department of Chemistry, Nigerian Defence Academy, Kaduna, Nigeria.
}

(Submitted: 02 May 2006; Accepted: 02 November 2006)

\begin{abstract}
The effect and mechanism of chloride ion attack on Portland cement concrete and the structural steel reinforcement was investigated.

At low concentrations, chloride ion has little or no effect on the physical stability of concrete structure but it causes the corrosion of the reinforcing steel in the concrete but at high concentration especially at low temperature, it causes expansion and cracking in the concrete. The degradation is usually accompanied by formation of calcium oxychloride salts. The mechanism for this destruction was due to the thermal transformation of the calcium oxychloride salts: $3 \mathrm{CaO} \cdot \mathrm{CaCl}_{2} \cdot 15 \mathrm{H}_{2} \mathrm{O}$ to $\mathrm{CaO} \cdot \mathrm{CaCl}_{2} \cdot 2 \mathrm{H}_{2} \mathrm{O}$.
\end{abstract}

\section{Introduction}

At low and moderate concentrations chloride ion has relatively little disruptive effect on the volume stability of the concrete. However, it destabilizes the passivating layers on steel reinforcement, Ramachandran (1976,1991).

At high concentrations, chloride ion affects the stability of concrete due to formation of basic chloride salts: calcium oxychloride (Sagoe-Crensil and Glasser, 1989a, 1989b). Chloride ions may be introduced into cement paste via internal and external sources. The internal sources include mixing-water, clinker and chloride-bearing aggregate or when calcium chloride is used as accelerating admixture. The external sources maybe through the use of sodium chloride as de-icing salt, by absorption of chloride ion from underground water or seawater. The chloride ions do not form compounds with the calcium silicate hydrate phases even though they accelerate the hydration of the calcium silicate phases (Birnin-Yauri and Glasser, 1991).

1.1 Corrosion of reinforcement steel

The reinforcing steel in concrete has a highly adhering thin $\gamma-\mathrm{Fe}_{2} \mathrm{O}_{3}$ film at the steel/concrete interface, which renders the steel passive to corrosion process. This protective thin layer is stable in the alkaline environment of hydrated cement $(\mathrm{pH}=13)$. The passivity may be destroyed by drop in the alkalinity of the environment in the vicinity of the steel surface to a level less than $\mathrm{pH} 11$. Such drop in $\mathrm{pH}$ is usually caused by concentration or the presence of chloride ions.

Chloride concentration of the order of 300 to 1200 $\mathrm{g} / \mathrm{dm}^{3}(8.0-34 \mathrm{M})$ in the pore fluid is reported to be sufficient to cause dissolution of the passive film (Goni and Andrade, 1990).
When a spot on the steel is depassivated the area becomes anode with respect to another area of steel that remains passive. Therefore, the passive area acts as cathode while the pore fluid acts as electrolyte. The following steps have been proposed as the mechanism by which rusting occurs. The initial anode reaction is the change from metallic iron to ferrous ions.

$$
\begin{aligned}
& F e_{(s)} \rightarrow F^{2+}(a x)+2 e^{-} \\
& e^{-}+H_{(a)}^{+} \rightarrow H_{(g)} \\
& 4 H_{(g)}+\mathrm{O}_{2(\xi)} \rightarrow 2 \mathrm{H}_{2} \mathrm{O}_{(\prime)} \\
& 4 \mathrm{Fe}_{(\mathrm{s} /)}^{2+}+\mathrm{O}_{2(g)}+(4+2 x) \mathrm{H}_{2} \mathrm{O}_{(n)} \rightarrow 2\left(\mathrm{Fe}_{2} \mathrm{O}_{3} \times \mathrm{H}_{2} \mathrm{O}\right)_{(s)}+18 \mathrm{H}_{(\mathrm{sg})}^{+} \text {(step4) }
\end{aligned}
$$

In step (1) ferrous ions are produced by loss of electrons from neutral Fe. This process cannot go very far unless there is some way to get rid of the electrons which accumulate on the residual Fe. One way to do this is by step (2) in which $\mathrm{H}^{+}$ions either from water or from acid substances in the water

$$
\left\{\text { e.g. } \mathrm{H}_{2} \mathrm{O}_{(l)}+\mathrm{CO}_{2(g)} \rightarrow \mathrm{HCO}_{3}{ }_{(\mathrm{(aq})}+\mathrm{H}^{+}(\mathrm{aq})\right\}
$$

pick up electrons to form neutral $H$ atoms. In the meantime, the ferrous ion from step (1) reacts with $\mathrm{O}_{2}$ gas by step (4) to form the rust and restore the $\mathrm{H}^{+}$ ion. The net reaction, obtained by adding all the four steps is:

$$
4 \mathrm{Fe}_{(x)}+3 \mathrm{O}_{2(g)}+2 x \mathrm{H}_{2} \mathrm{O} \rightarrow 2\left(\mathrm{Fe}_{2} \mathrm{O}_{3} \cdot x \mathrm{H}_{2} \mathrm{O}\right)_{(\dot{s})}
$$

Thus in the presences of oxygen and water the ferrous ions released in the corrosion process first form ferrous hydroxide:

$$
\mathrm{Fe}^{2+}+2 \mathrm{OH}^{-} \rightarrow \mathrm{Fe}(\mathrm{OH})_{2}
$$


In the presence of chloride ions, chlorocomplelexes of iron may form:

$$
4 \mathrm{Fe}(\mathrm{OH})_{2}+2 \mathrm{Cl}^{-} \rightarrow 3 \mathrm{Fe}(\mathrm{OH})_{2} \cdot \mathrm{FeCl}_{2}+2 \mathrm{OH}^{-}
$$

The chloro-iron complex is believed to be the intermediate product in the formation of $\beta-\mathrm{FeO} . \mathrm{OH}$ (akagamite) and other rust gelatinous products such as $\mathrm{Fe}_{2} \mathrm{O}_{3} \cdot \mathrm{xH}_{2} \mathrm{O}$ etc. (Birnin-Yauri, 1993).

Goni and Andrade (1990) are of the opinion that the pitting process of steel in chloride environment is as result of intense localized attack so that the steel bars become deeply notched. Goni and Andrade (1990), noted that for stable pit growth to be sustained, the local chloride ion concentration must rise and the local hydroxyl ion concentration must fall, otherwise repassivation is said to occur. Hence repassivation is now agreed to occur when the $\mathrm{Cl} / \mathrm{OH}$ ratio is equal to or more than $1 / 3$.

\subsection{Destabilisation of concrete}

At high chloride ion levels and particularly at low temperature, Portland is strongly attacked. Lawrence and Vivian (1960) reported that a strong Calcium chloride solution caused a severe damage to cement mortar when continuously stored in a $30 \%$ calcium chloride solution. They noted that the damage was because of expansion caused by formation of complex salts that they did not identify.

Similarly Chatterji and Jenson (1975) observed that a $30 \%$ calcium chloride solution at temperatures below $20^{\circ} \mathrm{C}$, caused degradation, swelling and cracking of Portland cement concrete Subsequently Chatterji (1978), demonstrated that a chemical reaction occurs between the hydrated cement and calcium chloride solution. He noted that when the cement paste was kept in 5-30\% calcium chloride solution at $4-50^{\circ} \mathrm{C}$ calcium aluminate monochloride hydrate $\left(3 \mathrm{CaO} \cdot \mathrm{Al}_{2} \mathrm{O}_{3} \cdot \mathrm{CaCl}_{2} \cdot \mathrm{xH}_{2} \mathrm{O}\right)$ was formed. $\mathrm{He}$ also noted that with calcium chloride solutions stronger than $15 \%$ and at temperatures lower than $20^{\circ} \mathrm{C}$, a complex salt containing $\mathrm{CaCl}_{2} \cdot \mathrm{Ca}(\mathrm{OH})_{2}$ and $/$ or $\mathrm{CaCO}_{3}$ could form. He finally concluded that the crystallization of this complex salt was responsible for the damage of the concrete. Monosi et al. (1990) studied the action of $30 \%$ calcium chloride solution on Portland cement paste by X-ray diffraction method on moist samples. Monosi and Collepardi (1989) studied the action of mixture of $\mathrm{Ca}(\mathrm{OH})$, and $\mathrm{CaCl}_{2}$ on Portland cement paste. They found the peaks for $3 \mathrm{CaO} \mathrm{CaCl}_{2} \cdot 15 \mathrm{H}_{2} \mathrm{O}(3.1 .15)$ only in the moist pastes and the peaks disappeared when the paste was ground or when it was dried at relative humanity of less than $1 \%$ or when washed in alcohol or water. According to literature, the solid phases in the system $\mathrm{CaO}-\mathrm{CaCl}_{2}-\mathrm{H}_{2} \mathrm{O}$ depending on the temperature, are $\mathrm{Ca}(\mathrm{OH})_{2}, 3 \mathrm{CaO} \cdot \mathrm{CaCl}_{2} \cdot 15 \mathrm{H}_{2} \mathrm{O}$, $\mathrm{CaO} \cdot \mathrm{CaCl}_{2} \cdot \mathrm{H}_{2} \mathrm{O}$ and $\mathrm{CaCl}_{2} \cdot 6 \mathrm{H}_{2} \mathrm{O}$.

The data in the literature on the stability of these compounds are incomplete. For cxample, they overlook the importance of the $\mathrm{pH}$ values of the solutions with which the salts co-existed. The $\mathrm{pH}$ values are essential to extend the data to predict the stability and solubility of the compound in those chemically more complex systems relevant to cements.

\section{Experimental Procedure}

\subsection{Preparation of Sample}

All the chemical reagents used were of analytical grade unless otherwise stated. The reagents included chemically pure grades of $\mathrm{CaCl}_{2} \cdot 2 \mathrm{H}_{2} \mathrm{O}$ and $\mathrm{CaCO}_{3}$. The latter was calcined at $1200{ }^{\circ} \mathrm{C}$ and the resultant fresh lime was used. Then the $\mathrm{CaO}$ was added to the calcium chloride solution. Before adding $\mathrm{CaO}$ to the calcium chloride solutions the containing plastic bottle was first immersed into a cool water bath to avoid melting the containers because of the large hydration heat of $\mathrm{CaO}$. A series of samples were prepared in the ratio $\mathrm{CaO}: \mathrm{CaCl}_{2} \mid=1: 9$ to $9: 1$. The paste or slurry so produced was kept in sealed plastic bottles at $20 \pm 5{ }^{\circ} \mathrm{C}$ with intermittent agitation for four weeks.

After four weeks each sample was filtered inside a large polythene bag filled with nitrogen. This was to avoid or minimize absorption of the atmospheric gasses especially carbon dioxide.

\subsection{Characterization of the Solid Phase}

The solid was characterized by x-ray diffraction method using Philips PW1710 diffractometer with CuKa radiation ran at $6^{\circ}$ or $20^{\circ} 20 / \mathrm{min}$. The diffractogram were compared to standards for identification (JCPDS, 1991).

\subsection{Analysis of the Aqueous Phase}

The filtrates were further filtered with fine filter papers (Millipore ${ }^{\mathrm{TM}}$ ) of $0.45 \mu \mathrm{m}$ pore size. The finely filtered solutions were subjected to analyses to determine concentration of calcium using atomic absorption spectroscopic ( $\mathrm{A} \wedge \mathrm{S}$ ) method (Varma, 1984). A Pye Unicam SP9 spectrometer was used. Colorimetric method (Thomas and Chamberlin, 1980) was adopted for determination of chloride ion. Hydroxyl ion was determined by titration with 0.05 $\mathrm{M} \mathrm{HCl}$, with phenolphthalein as indicator. The $\mathrm{pH}$ was subsequently determined using the relationship: $\mathrm{pH}=14+\log \left[\mathrm{OH}^{-}\right]$.

In the case of sample with $\mathrm{Cl} / \mathrm{OH}$ ratio, i.e., low hydroxyl content, the pH was directly mensured using a P'TL-6 Universal Digital pH meter fitted with Russell CTGL/NH/GEL, glass electrode. The pH meter was calibrated with stanclard pH 4, 7 and 12 buffer solutions.

\subsection{Results and Disctussion}

Table 1 below shows the hydration products of the various samples and the analysis of the aqueous phase in which they were in equilibrium.

Table 1: shows that al $20^{\circ} \mathrm{C}$, threc solic phases cxist in the system $\mathrm{CaO} \mathrm{CaCl}_{2}-\mathrm{I}_{2} \mathrm{O}$. These phases are 
$\mathrm{Ca}(\mathrm{OH})_{2}, 3 \mathrm{CaO} \cdot \mathrm{CaCl}_{2} .15 \mathrm{H}_{2} \mathrm{O}(3.1 .15)$ and $\mathrm{CaO} . \mathrm{CaCl}_{2} \cdot 2 \mathrm{H}_{2} \mathrm{O}(1.1 .2)$. These results agree with those of Schreinemakers and Figee (1989) who studied the system at $25^{\circ} \mathrm{C}$. It can be seen that of the various hydrates of calcium chloride (i.e. $\mathrm{CaCl}_{2} . \mathrm{H}_{2} \mathrm{O}$, $\mathrm{CaCl}_{2} \cdot 2 \mathrm{H}_{2} \mathrm{O}, \mathrm{CaCl}_{2} \cdot 4 \mathrm{H}_{2} \mathrm{O}$ and $\left.\mathrm{CaCl}_{2} \cdot 6 \mathrm{H}_{2} \mathrm{O}\right)$, it is indicated in Tablel that only $\mathrm{CaCl}_{2} \cdot 6 \mathrm{H}_{2} \mathrm{O}$ exists at $20^{\circ} \mathrm{C}$.

The system $\mathrm{CaO}-\mathrm{CaCl}_{2}-\mathrm{H}_{2} \mathrm{O}$ was studied by $\mathrm{O}^{\prime} \mathrm{Connor}(1972)$ at $\mathrm{O}{ }^{\circ} \mathrm{C}$. The results indicate that there are only three solid phases in the system at that temperature. These phases are $\mathrm{Ca}(\mathrm{OH})_{2}$, $3 \mathrm{CaO} \cdot \mathrm{CaCl}_{2} \cdot 15 \mathrm{H}_{2} \mathrm{O}$ and $\mathrm{CaCl}_{2} \cdot 6 \mathrm{H}_{2} \mathrm{O}$. Millikan (1961) studied the same system at $40^{\circ} \mathrm{C}, 45^{\circ} \mathrm{C}$ and $50^{\circ} \mathrm{C}$. Millikan's results show that $\mathrm{CaCl}_{2} \cdot 6 \mathrm{H}_{2} \mathrm{O}$ and $3 \mathrm{CaO} \cdot \mathrm{CaCl}_{2} \cdot 15 \mathrm{H}_{2} \mathrm{O}$ were not stable at temperatures above $40^{\circ} \mathrm{C}$.

It is apparent that the range of existence of $3 \mathrm{CaO} \cdot \mathrm{CaCl}_{2} \cdot 15 \mathrm{H}_{2} \mathrm{O}$ increases as the temperature falls. The amount of water of crystallization of calcium chloride hydrate decreases with increasing temperature as indicated in the equation below (Demidot et al., 1994).

$$
\begin{aligned}
& \mathrm{CaCl}_{2}+\mathrm{H}_{2} \mathrm{O} \rightarrow \mathrm{CaCl}_{2} \cdot 6 \mathrm{H}_{2} \mathrm{O} \text { at } 30{ }^{\circ} \mathrm{C} \text { and }[\mathrm{Cl}]=9 \mathrm{M} \\
& \mathrm{CaCl}_{2} \cdot 6 \mathrm{H}_{2} \mathrm{O} \rightarrow \mathrm{CaCl}_{2} \cdot 4 \mathrm{H}_{2} \mathrm{O} \text { at } 30-45^{\circ} \mathrm{C} \text { and }[\mathrm{Cl}]=9-10 \mathrm{M} \\
& \mathrm{CaCl}_{2} \cdot 4 \mathrm{H}_{2} \mathrm{O} \rightarrow \mathrm{CaCl}_{2} \cdot 2 \mathrm{H}_{2} \mathrm{O} \text { at } 40-80^{\circ} \mathrm{C} \text { and }[\mathrm{Cl}]=10-13 \mathrm{M} \\
& \mathrm{CaCl}_{2} \cdot 2 \mathrm{H}_{2} \mathrm{O} \rightarrow \mathrm{CaCl}_{2} \cdot \mathrm{H}_{2} \mathrm{O} \text { at } 180-260^{\circ} \mathrm{C} \text { and }[\mathrm{Cl}]=13-14 \mathrm{M} \text {. }
\end{aligned}
$$

These equations show that the amount of water of crystallization of calcium chloride hydrate depends both on the temperature and the chloride concentration of the aqueous phase.

Monosi and Collepardi (1990) reported the transformation of $3 \mathrm{CaO} \cdot \mathrm{CaCl}_{2} \cdot 15 \mathrm{H}_{2} \mathrm{O}$ into $\mathrm{CaO} \cdot \mathrm{CaCl}_{2} \cdot 2 \mathrm{H}_{2} \mathrm{O}$ with increase in temperature and the reverse with fall in temperature. This is affirmed by noting the absence of $\mathrm{CaO} \cdot \mathrm{CaCl}_{2} \cdot 2 \mathrm{H}_{2} \mathrm{O}$ in the system at $0{ }^{\circ} \mathrm{C}$. similarly $3 \mathrm{CaO} \cdot \mathrm{CaCl}_{2} \cdot 15 \mathrm{H}_{2} \mathrm{O}$ no longer exists at $40{ }^{\circ} \mathrm{C}$ and above. Therefore, when in contact with solution the transformation of the solids can be represented as:

$3 \mathrm{CaO} . \mathrm{CaCl}_{2} \cdot 15 \mathrm{H}_{2} \mathrm{O}_{(\mathrm{s})} \rightarrow \mathrm{CaO} . \mathrm{CaCl} 2.2 \mathrm{H}_{2} \mathrm{O}_{(\mathrm{s})}+2 \mathrm{Ca}(\mathrm{OH})_{2(s)}+1 \mathrm{H}_{2} \mathrm{O}_{(i)}$

So, the formation of $3 \mathrm{CaO} \cdot \mathrm{CaCl}_{2} \cdot 15 \mathrm{H}_{2} \mathrm{O}$ is favoured by the decrease in the chloride content necessary to form $3 \mathrm{CaO} \cdot \mathrm{CaCl}_{2} .15 \mathrm{H}_{2} \mathrm{O}$. Hence its formation in weaker chloride solutions becomes more feasible. Thus for a similar chloride attack more $3 \mathrm{CaO} . \mathrm{CaCl}_{2} .15 \mathrm{H}_{2} \mathrm{O}$ is formed at temperatures lower than $40^{\circ} \mathrm{C}$. This explains the observation of more severe chloride attack on cement paste at temperatures below $5^{\circ} \mathrm{C}$. At $20^{\circ} \mathrm{C}$, the nature of the solid phases in the system changes with the change of the chloride concentration in the solution. The sequence of occurrence of the solids with increasing chloride is as shown in Table 2.

Table 2 indicates that $\mathrm{Ca}(\mathrm{OH})_{2}$, which is a major hydrate in cement paste, is not stable at chloride concentrations higher than 3 moles per litre.

At $20{ }^{\circ} \mathrm{C}$, the system $\mathrm{CaO}-\mathrm{CaCl}_{2}-\mathrm{H}_{2} \mathrm{O}$ consists of three isothermal invariant points at which two solid phases co-exist with solution. These are:

$$
\begin{aligned}
& \mathrm{CaCl}_{2} \cdot 6 \mathrm{H}_{2} \mathrm{O}+\mathrm{CaO} \cdot \mathrm{CaCl}_{2} \cdot 2 \mathrm{H}_{2} \mathrm{O} \\
& \mathrm{CaO} \cdot \mathrm{CaCl}_{2} \cdot 2 \mathrm{H}_{2} \mathrm{O}+3 \mathrm{CaO} \cdot \mathrm{CaCl}_{2} \cdot 15 \mathrm{H}_{2} \mathrm{O} \\
& 3 \mathrm{CaO} \cdot \mathrm{CaCl}_{2} \cdot 15 \mathrm{H}_{2} \mathrm{O}+\mathrm{Ca}(\mathrm{OH})_{2}
\end{aligned}
$$

A saturated aqueous solution of $\mathrm{Ca}(\mathrm{OH})_{2}$ at $20^{\circ} \mathrm{C}$ was found to contain $0.019 \mathrm{M} \mathrm{Ca}$ and had a $\mathrm{pH}$ value of 12.58. Similarly an aqueous solution in which $\mathrm{CaCl}_{2} .6 \mathrm{H}_{2} \mathrm{O}$ was stable contained $4.034{\text { mol. } \mathrm{dm}^{-3}}^{-3}$ $\mathrm{Ca}^{2+}$ and $8.06 \mathrm{~mol}^{2} \mathrm{dm}^{-3} \mathrm{Cl}^{-}$with a pH value of 4.77 .

\section{Conclusions}

In this work it is interestingly discovered that in the system $\mathrm{CaO}-\mathrm{CaCl}_{2}-2 \mathrm{H}_{2} \mathrm{O}$ at temperatures above 40 ${ }^{\circ} \mathrm{C}$, the predominant solid is $\mathrm{CaO} \cdot \mathrm{CaCl} 2.2 \mathrm{H}_{2} \mathrm{O}$ with a density of $2.40 \mathrm{~g} / \mathrm{dm}^{3}$. As the temperature falls to less than $20^{\circ} \mathrm{C}$, this solid is converted to another solid $3 \mathrm{CaO} . \mathrm{CaCl}_{2} .15 \mathrm{H}_{2} \mathrm{O}$ with a density of $1.805 \mathrm{~g} /$ $\mathrm{dm}^{3}$ This transformation is therefore accompanied by almost $25 \%$ increase in volume (decreases in density) and hence the reason for the expansion observed in concrete especially at low temperatures. The loss of eleven molecules of water as shown in the conversion equation, indicates increase in porosity of the concrete, which in turn weakens the structure.

The transformation of $\mathrm{CaO} \cdot \mathrm{CaCl}_{2} \cdot 2 \mathrm{H}_{2} \mathrm{O}$ to $3 \mathrm{CaO} \cdot \mathrm{CaCl}_{2} \cdot 15 \mathrm{H}_{2} \mathrm{O}$ can be represented by the equation:

$\mathrm{CaO} \cdot \mathrm{CaCl}_{2} \cdot 2 \mathrm{H}_{2} \mathrm{O}+2 \mathrm{Ca}(\mathrm{OH})_{2}+11 \mathrm{H}_{2} \mathrm{O} \rightarrow 3 \mathrm{CaO}^{-\mathrm{CaCl}_{2}} \cdot 15 \mathrm{H}_{2} \mathrm{O}$

In isochemical condition, this transformation depletes $\mathrm{Ca}(\mathrm{OH})_{2}$ from the system and hence the $\mathrm{pH}$ is reduced. Such a fall in $\mathrm{pH}$ may cause the destabilization of the hydration products like $3 \mathrm{CaO} \cdot \mathrm{Al}_{2} \mathrm{O}_{3} \cdot 3 \mathrm{CaSO}_{4} \cdot 32 \mathrm{H}_{2} \mathrm{O}$ (ettringite) and $3 \mathrm{CaO} \cdot \mathrm{Al}_{2} \mathrm{O}_{3} \cdot \mathrm{CaSO}_{4} \cdot 12 \mathrm{H}_{2} \mathrm{O}$ (monosulphate) (Gabrisova et al., 1991) and even $3 \mathrm{CaO} \cdot \mathrm{Al}_{2} \mathrm{O}_{3} \cdot \mathrm{CaCl}_{2} \cdot 10 \mathrm{H}_{2} \mathrm{O}$ (Friedel's salt) (Ben-Yair, 1971). The increase in the density during the conversation means decrease in volume i.e. contraction. In dry desert areas, the temperature difference between day and night could be up to 40 ${ }^{\circ} \mathrm{C}$. Such temperature fluctuations would cause the formation of $3 \mathrm{CaO}^{-\mathrm{CaCl}_{2}} \cdot 15 \mathrm{H}_{2} \mathrm{O}$ at night and its transformation to $\mathrm{CaO} \cdot \mathrm{CaCl}_{2} \cdot 2 \mathrm{H}_{2} \mathrm{O}$ by the day. The expansion-contraction cycle could cause cracking and degradation of the concrete. 


\section{REFERENCES}

Ben-Yair, M., 1971. Studied on the Stability of Calcium Chloroaluminate. Isr. J Chem, 9, 529-536.

Birnin-Yauri, U.A., 1993. Chloride in Concrete Study of the System $\mathrm{CaO}-\mathrm{Al}_{2} \mathrm{O}_{3}-\mathrm{CaCl}_{2}-\mathrm{H}_{2} \mathrm{O}$. Ph.D Thesis Submitted to Department of Chemistry, University of Aberdeen, Scotland U.K.

Birnin-Yauri, U.A. and Glasser, F.P., 1991. Chloride in Cement Phase Studied of the $\mathrm{Ca}(\mathrm{OH})_{2}-\mathrm{CaCl}_{2}-\mathrm{H}_{2} \mathrm{O}$ System. II Cemento, 88 (3), 151-157.

Cannot, E., 1986. Cement with Quick setting Time. Mon. Ind. Belge, 12, 182.

Chatterji, S., 1978. Mechanism of $\mathrm{CaCl}_{2}$ Attack on Portland Cement Concrete. Cem. Conc. Res., 8, 461-468.

Demodiuk, T., Cole, W.F. and Hauever, H.V., 1955. Studied on Magnesium and Calcium Oxychlorides. Aust. J. Chem., 8, 215.

Demidot, D., Birnin-Yauri, U.A. and Glasser, F.P., 1994. Thermodynamic Investigation of the System at $25^{\circ} \mathrm{C}$ and the Influence of $\mathrm{Na}_{2} \mathrm{O}$. Il Cemento, 91(4), 243254.

Gabrisova, A., Havica, J. and Sahu, A., 1991. Stability of Calcium Sulphoalumimnates in water solution with various pH Values. Cem. Conc. Res., 21(6), 10231027.

Goni, S. and Andrade, C., 1990. Synthetic Concrete Pore Solution Chemistry and Rebar Corrosion Rate in the Presence of Chloride. Cem. Conc. Res., 20(4), 525. 539.

JCPDS, 1991. Alphabetical Inorganic Powder Diffraction File, International Centre for Diffraction Data (ICDD) Swarthmore PA, USA.

Kallaumer, O., 1962. The Influence of $\mathrm{CaCl}_{2}$ in Cement and Concrete Practice with Special Reference to its Use as an Acceleration of Cement Hydration. Annal Tech. College Burno, 2, 97.
Lawrence, M. and Vivian, H.E., 1960. The Action of $\mathrm{CaCl}_{2}$ on Mortar and Concrete. Cand. J. App Science, 11, 4.

Linke, F.W., 1958. Solubilities of Inorganic and Metal Organic Compound. American Chemical Society, van Nostrand Co. Inc. Princeton. vol. 1 pp. 565-570.

Milikan, J., 1961. The Oxyhalide der Alkalisechen Erden I. Zur Phys Chem 92(1), 59-80.

Monosi, S., Alvera, I. and Collepardi, M., 1989. Chemical Attack of Calcium Chloride on Cement Paste. Il Cemento, 2, 97-104.

Monosi, S. and Collepardi, M., 1990. Research on $3 \mathrm{CaO} \mathrm{CaCl}$ $15 \mathrm{H}_{2} \mathrm{O}$ Identified in Concrete Damaged by $\mathrm{CaCl}_{2}$ Attack. Il Cemento 1, 3-8.

O'Connor, E.A. 1972. The Compassion of Bleaching Powder. J. Chem. Soc., 11, 2700-2710.

Ramachandran, V.S., 1976. Calcium Chloride in Concrete Science and Technology. Applied Science Publishers, London.

Ramchandran, V.E., 1991. Possible State of Chloride in the Hydration of Tricalcium Silicate in the Presence of Calcium Chloride.| Mater. et Constr., 4(19), 3-12.

Sagoe-Crentsil, K.K. and Glasser, F.P., 1989a. Steel in Concrete Part 1. A Review of Electrochemical Aspects. Mag. Conc. Res., 41(149), 205-212.

Sagoe-Crentsil, K.K. and Glasser F.P., 1989b. Steel in Concrete Part 11 Electron Microscopy. Mag. Conc. Res., 41(149), 213-220.

Schreinemakers, F.A and Figee, T., 1989. The Study of System: $\mathrm{H}_{2} \mathrm{O}-\mathrm{CaCl}, \mathrm{Ca}(\mathrm{OH})_{2}$ at $25^{\circ} \mathrm{C}$. Chemisch. Weekblad. 8, 683-688.

Thomas, L.C. and Chamberlin, G.J., 1999. Colorimetric Chemical Analytical Methods, (9th Ed.), The Tintometer Ltd, Salibury, England.

Varma, A., 1984. CRC Handbook of Atomic Absorption Analysis, CRC Press, Boca Raton, USA. 
Table 1: The system $\mathrm{CaO}-\mathrm{CaCl}_{2}-\mathrm{H}_{2} \mathrm{O}$ at $20^{\circ} \mathrm{C}$

\begin{tabular}{|c|l|c|c|c|c|}
\hline $\begin{array}{c}\text { Sample } \\
\left(\mathrm{CaO}: \mathrm{CaCl}_{2}\right)\end{array}$ & \multicolumn{1}{|c|}{ Solid Phase } & \multicolumn{3}{|c|}{ Aqueous Phase (mol/dm $\left.{ }^{3}\right)$} & $\mathbf{p H}$ \\
\hline & & $\mathbf{C a}$ & $\mathbf{C l}$ & $\mathbf{O H} \times \mathbf{1 0}^{-3}$ & \\
\hline $1: 9$ & $\mathrm{CaCl}_{2} .6 \mathrm{H}_{2} \mathrm{O}$ & 4.034 & 8.068 & - & 5.77 \\
\hline $2: 8$ & $1.1 .2+3.1 .15$ & 3.084 & 6.076 & 3.70 & 11.57 \\
\hline $3: 7$ & $1.1 .2+3.1 .15$ & 3.036 & 5.985 & 4.50 & 11.65 \\
\hline $4: 6$ & 3.1 .15 & 2.694 & 5.232 & 6.70 & 11.83 \\
\hline $5: 5$ & 3.1 .15 & 2.218 & 4.384 & 7.20 & 11.86 \\
\hline $6: 4$ & 3.1 .15 & 2.170 & 4.289 & 27.90 & 11.90 \\
\hline $7: 3$ & $3.1 .15+\mathrm{Ca}(\mathrm{OH})_{2}$ & 1.662 & 3.271 & 28.20 & 12.45 \\
\hline $8: 2$ & $\mathrm{Ca}(\mathrm{OH})_{2}$ & 1.389 & 2.728 & 35.50 & 12.55 \\
\hline $9: 1$ & $\mathrm{Ca}(\mathrm{OH})_{2}$ & 0.922 & 1.902 & 39.80 & 12.60 \\
\hline
\end{tabular}

Key: $1.1 .2=\mathrm{CaO} . \mathrm{CaCl}_{2} .2 \mathrm{H}_{2} \mathrm{O}$

$3.1 .15=3 \mathrm{CaO} \mathrm{CaCl}_{2} \mathrm{I}_{2} \mathrm{H}_{2} \mathrm{O}$

Table 2: Solid Phases Formed with Variation of $[\mathrm{Cl}]$ in the solution at $20^{\circ} \mathrm{C}$

\begin{tabular}{|l|l|}
\hline$\left[\mathrm{CII}\left(\mathrm{mol} / \mathbf{d m}^{3}\right)\right.$ & Solid Phase \\
\hline $0.00-3.00$ & $\mathrm{Ca}(\mathrm{OH})_{2}$ \\
$3.00-6.00$ & $3 \mathrm{CaO} \cdot \mathrm{CaCl}_{2} \cdot 15 \mathrm{H}_{2} \mathrm{O}$ \\
$6.00-8.00$ & $\mathrm{CaO} \cdot \mathrm{CaCl}_{2} .2 \mathrm{H}_{2} \mathrm{O}$ \\
$8.00-9.00$ & $\mathrm{CaCl}_{2} \cdot 6 \mathrm{H}_{2} \mathrm{O}$ \\
\hline
\end{tabular}

Table3: Composition of the invariant point.

\begin{tabular}{|c|c|c|c|c|}
\hline Invariant Point & \multicolumn{3}{|c|}{ Aqueous Phase ( $\left.\mathrm{mol}^{\prime} / \mathrm{dm}^{3}\right)$} & pH \\
\hline & $\mathrm{Ca}$ & $\mathrm{Cl}$ & $\mathrm{OH} \times 10^{-5}$ & \\
\hline $\begin{array}{c}\mathrm{CaCl}_{2} \cdot 6 \mathrm{H}_{2} \mathrm{O}+ \\
\mathrm{CaO} \cdot \mathrm{CaCl}_{2} \cdot 2 \mathrm{H}_{2} \mathrm{O}\end{array}$ & 4.027 & 8.053 & 0.0046 & 8.66 \\
\hline $\begin{array}{l}\mathrm{CaO} \cdot \mathrm{CaCl}_{2} \cdot 2 \mathrm{H}_{2} \mathrm{O}+ \\
3 \mathrm{CaO} \cdot \mathrm{CaCl}_{2} \cdot 15 \mathrm{H}_{2} \mathrm{O}\end{array}$ & $3.08 \overline{4}$ & 6.076 & 2.00 & 11.30 \\
\hline $\begin{array}{l}3 \mathrm{CaO}^{-\mathrm{CaCl}_{2}} \cdot 15 \mathrm{H}_{2} \mathrm{O}+ \\
\mathrm{Ca}(\mathrm{OH})_{2} .\end{array}$ & 1.635 & $3.2 \overline{71}$ & 22.40 & 12.35 \\
\hline
\end{tabular}

